\title{
High Quality DNA Obtained from a Single Seed of Vitis vinifera L. Using Rapid DNA Extraction Method
}

\author{
Ajith Samantha Rathnayake ${ }^{1,2}$, Josep Allué1, Mercè Llugany ${ }^{1 *}$, Anna Puig-Pujol ${ }^{3}$, \\ Kshanika Hirimburegama ${ }^{2}$, Charlotte Poschenrieder ${ }^{1}$ \\ ${ }^{1}$ Plant Physiology Laboratory, Faculty of Biosciences, Autonomous University of Barcelona (UAB), \\ Bellaterra, Spain \\ ${ }^{2}$ Department of Plant Sciences, Faculty of Science, University of Colombo, Colombo, Sri Lanka \\ ${ }^{3}$ Department of Agriculture, Research and Technology Food and Agriculture Institute (IRTA)-Catalan \\ Institute of Vine and Wine (INCAVI), Vilafranca del Penedés, Spain \\ Email: ${ }^{*}$ merce.llugany@uab.cat
}

Received 29 April 2014; revised 28 May 2014; accepted 19 June 2014

Copyright (C) 2014 by authors and Scientific Research Publishing Inc.

This work is licensed under the Creative Commons Attribution International License (CC BY).

http://creativecommons.org/licenses/by/4.0/

(c) (i) Open Access

\begin{abstract}
Use of a single seed is very useful for genetic studies on Vitis vinifera. However, molecular markers require a fair amount of high purity DNA. Grapevine contains high concentrations of polysaccharides, polyphenols, tannins and other secondary metabolites. These compounds may hamper the DNA isolation processes and subsequent analysis. In this study we have compared two DNA isolation methods: the NucleoSpin Plant II method and a modified protocol from Doyle and Doyle. The average value of $260 / 280 \mathrm{~nm}$ absorption ratio, which is used to assess the purity of DNA and RNA was 1.8 (accepted as "pure" DNA) and 0.9 (presence of protein or other contaminants) for the first and second method, respectively. Using the NucleoSpin protocol, from a single seed (20 - $35 \mathrm{mg}$ ) we obtained an average yield of extracted DNA of $24.8 \pm 5.2$ to $38.4 \pm 11.5 \mathrm{ng}^{-\mathrm{mg}^{-1}} \mathrm{dry}^{\text {weight. }}$ Among the two protocols examined, the NucleoSpin method was more efficient and gave better quality of DNA values compared to those from the modified Doyle and Doyle procedures.
\end{abstract}

\section{Keywords}

Vitis, Single Seed, High Quality DNA, DNA Extraction Method

\section{Introduction}

The European grapevine (Vitis vinifera L.) belonging to the Vitaceae family is one of the oldest and most im-

Corresponding author.

How to cite this paper: Rathnayake, A.S., Allué, J., Llugany, M., Puig-Pujol, A., Hirimburegama, K. and Poschenrieder, C. (2014) High Quality DNA Obtained from a Single Seed of Vitis vinifera L. Using Rapid DNA Extraction Method. American Journal of Plant Sciences, 5, 2023-2030. http://dx.doi.org/10.4236/ajps.2014.513217 
portant perennial crops in the world. The cultivated grapevine is diploid and has relatively small genome size of 475 - $500 \mathrm{Mb}$ compared to many other perennial plant species [1]. In fact, the quantity and quality of genomic DNA will undeniably determine the outcome of any molecular studies. Recently, this plant has been used for gene mapping [2]-[4], genetic transformation [5], and DNA fingerprinting [6] [7].

DNA can be extracted from different plant parts of the grapevines, mostly leaves and stems but also seeds. Although in the last few years DNA extraction methods require less quantities of material than before, DNA extraction from a single seed is difficult both due to the very small amount of biomass and the high quantity of lignified tissue, present in this recalcitrant structure. Moreover, molecular markers require a fair amount of high purity DNA and it is often not easy to separate DNA from naturally occurring plant cell contaminants. The genomic grapevine DNA extraction is difficult, especially when young leaves are unavailable. In fact, it is known that mature grapevine leaves contain high quantities of secondary metabolites, such as polysaccharides, polyphenols and tannins [8]-[10]. In addition, abiotic stress such as water and nutritional deficiencies or pathogenic infection can significantly enhance the biosynthesis and accumulation of these secondary compounds [11].

These compounds have also been reported to cause difficulty in DNA purification in other plant species [12] [13]. When plant cells are destroyed, these cytoplasmic contaminants come into contact with nuclei and other organelles, representing a major obstacle in DNA purification [14]. In particular, polyphenolic compounds can irreversibly bind proteins and nucleic acids to form high-molecular weight complexes [15], whereas polysaccharides tend to co-precipitate with DNA [16] [17], making the DNA viscous and un-amplifiable in polymerase chain reaction (PCR). Therefore, these compounds must be eliminated during DNA isolation.

DNA extraction from a single seed of Vitis vinifera L. can be a very useful tool available during all the years for a variety of genetic and breeding studies such as determination of the still poorly known geographical origins and spread of grape cultivation, gen sources, parent assignation and on evolution studies. Studies with ancient grape seeds have been often forced to use several seeds from an archaeological site, to achieve an appropriate amount of material in order to obtain the necessary amount of DNA for genetic studies, with the inconvenience that they can belong to different varieties.

There are many recent papers focusing on the improvement of DNA extraction methods to increase yield and purity as well as to reduce experimental time but they still use a fair amount of sample material: $0.05-0.1 \mathrm{~g}$ young leaf [18] [19] or 0.2 g seeds [20]. To our best knowledge, there is only one report on DNA extraction from single seeds of Vitis vinifera [21].

As seeds are a source of genetic material, easy to preserve and available during all the year, the main objective of this study is the improvement of DNA extraction procedure so as to obtain the maximum yield and quality of DNA from single seeds of Vitis vinifera ranging from 0.02 to $0.035 \mathrm{~g}$ weight.

\section{Materials and Methods}

\subsection{Plant Materials}

Grape (Vitis vinifera L.) seeds were obtained from the InstitutCatala de la Vinya i el Vi (INCAVI) station at Vilafranca del Penedès, Spain. The plant material used for comparison of DNA extraction methods included three grape cultivars (Malbec, Caladoc and Petit Verdot) seeds. Those seeds were collected from the vineyards of three different locations from Alt Penedès region in Catalonia, Spain; Malbec from Moja (Olèrdola), Caladoc from Sant Pau d'Ordal (Subirats) and Petit Verdot from El Pla del Penedès. A total of 45 grape seeds were analyzed (15 seeds from each variety). Seeds were divided in three classes according to their weight (small 20 - 25 mg, medium 25 - $30 \mathrm{mg}$ and large 30 - $35 \mathrm{mg}$ ) and 5 replicates per class and variety were analyzed.

\subsection{DNA Isolation from Grapevine Seeds}

After obtaining the seeds, those were kept at $4^{\circ} \mathrm{C}$ until used. Each seed was crushed separately by using pre cooled mortar and pestle and then was mechanically disrupted using a Mikro-Dismembrator (laboratory ball mills for fine grinding) with three grinding balls. Then well homogenized seed samples were put in to $1.5 \mathrm{~mL}$ micro centrifuge tubes and DNA was extracted as follows. Two DNA extraction methods, the NucleoSpin ${ }^{\circledR}$ Plant II kit (referred to as NucleoSpin method) with minor modifications (MACHEREY-NAGEL, Germany) and the modified Doyle and Doyle method [22] were examined. NucleoSpin kit offers two different lysis buffers for optimal processing. The standard protocol uses lysis buffer-PL1 based on cetyltrimethyl ammonium bromide (CTAB). The additional one uses lysis buffer-PL2 based on sodium dodecyl sulfate (SDS). The lysis efficiency 
is different based on the negative charge of SDS and the positive charge of CTAB. Since both CTAB and SDS based extraction yields were similar (data not shown), we used only the standard protocol with CTAB based extraction for this study.The modified Doyle and Doyle method uses 3\% CTAB and an elution buffer based on 10 $\mathrm{mMTris} / \mathrm{HCl}, 1 \mathrm{mM}$ EDTA at $\mathrm{pH} 8.0$ while the NucleoSpin method uses $5 \mathrm{mMTris} / \mathrm{HCl}$ at $\mathrm{pH}$ 8.5. DNA was dissolved in both methods with $75 \mu \mathrm{L}$ of the corresponding elution buffer and was stored at $-20^{\circ} \mathrm{C}$ for further processing.

\subsection{HHEstimation of DNA Quality and Quantity}

The yield and purity of extracted DNAs were measured first spectrophotometrically using a NanoDrop 1000 Spectrophotometer (Thermo Scientific) with UV absorption at a wavelength of $260 \mathrm{~nm}$ (nucleic acids absorbing wavelength) and $280 \mathrm{~nm}$ (proteins absorbing wavelength) and second by an electrophoretical method based on $0.6 \%(\mathrm{w} / \mathrm{v})$ agarose gel using ethidium bromide fluorescence in comparison to a known amount of lambda DNA molecular weight marker, as described by Sambrook et al. [23]. The electrophoresis of seed genomic DNA on agarose gel showed quality of DNA bands for each sample. Each one contained $20 \mu \mathrm{L}$ of extracted DNA and 2 $\mu \mathrm{L}$ loading buffer that was put into the agarose gel sumps and loaded off in $1 \mathrm{X}$ TBE buffer condition (89 mMTris, $89 \mathrm{mM}$ boric acid, $2 \mathrm{mM}$ EDTA at $\mathrm{pH}$ 8). EcoRI and HindIII digested lambda DNA was used as molecular size marker $(0.12-21.2 \mathrm{kbp})$. Agarose gel was under a steady voltage of $100 \mathrm{~V}$ for $30 \mathrm{~min}$ and then stained with ethidium bromide $\left(20 \mathrm{mg} \cdot \mathrm{mL}^{-1}\right)$. The results were visualized on a UV transilluminator and photographed by gel documentation system Quantity one 1-DV.4.6.9. analysis software (Bio-Rad).

\subsection{Data Analysis}

In this study, the DNA data were analyzed using Microsoft Office Excel program and effect of the DNA yield on the seed weight classes (small, medium and large) as well as three cultivars (Malbec, Caladoc and Petit Verdot) were compared using student t-test.

\section{Results and Discussion}

\subsection{DNA Extraction of Single Seed of Grapevine}

Approximately 20 - 35 mg of dry weight of single grapevine seed was used for the genomic DNA isolation using two DNA extraction protocols. According to the results of this study, the amount of extracted DNA was very low but it was enough for genetic studies after PCR amplification. Grapevine contains high concentrations of metabolites [8] [9] that may hamper the DNA isolation processes and subsequent analysis [24]-[26]. Given that the grape seeds are more lignified than young and mature leaves we expected greater difficulty in extracting DNA from a single seed, but the extraction protocol using CTAB proved efficacious compared to the modified Doyle and Doyle procedure in aspect of quality of DNA extracted from a single seed of Vitis vinifera. According to the higher density of useless compounds such as polysaccharides and polyphenols in mature seeds, the selection of more efficient DNA extraction procedures is important. Eventually, proper concentrations of chemicals and shorter length of time is also important for extraction of high quality DNA from the mature plant parts. The NucleoSpin method is the best extraction procedure due to the less time requirement and the use of few chemicals for the DNA extraction process. According to manufacturer specifications, the NucleoSpin kit is designed for the isolation of genomic DNA from plant tissues using an optimized lysis buffers, conveniently clearing the crude lysates, remove RNA to allow photometric quantification, the optimized binding buffer and the chaotropic wash buffer for completely remove proteins, RNA, metabolites, and other PCR inhibitors.

The volume of elution buffer used in the elution steps was the most important parameter to obtain maximum amount of DNA concentration from a single seed. We used $50 \mu \mathrm{L}$ in step 1 and $25 \mu \mathrm{L}$ in step 2 with a resulting final elution volume of $75 \mu \mathrm{L}$. It is possible even to improved yield by reusing the $50 \mu \mathrm{L}$ from step 1 again in step 2 resulting in an elution volume of only $50 \mu \mathrm{L}$.

\subsection{Quality and Quantity of the Extracted DNA}

The quality and quantity of extracted genomic DNA was tested with two methods; the spectrophotometrical method and the electrophoretical one based on agarose gel (Figure 1). The results obtained from the spectro- 
photometric method and the quality and the quantity of DNA from the both extraction methods are given in Table 1. By spectrophotometric procedure, absorption of double-stranded DNA in a wavelength of $260 \mathrm{~nm}$ is 50 $\mu \mathrm{g} \cdot \mu \mathrm{L}^{-1}$. When the ratio of absorption $260 / 280 \mathrm{~nm}$ is between 1.7 and 2 , it shows that most absorption is done by nucleic acids and therefore extracted DNA is well qualified and its purity acceptable. Our results indicate that extracted DNA executed by NucleoSpin method showed better quality in comparison with the modified CTAB method (Table 1).

The spectrophotometric data showed that in all seed classes (small, medium and large seeds) of the three varieties (Malbec, Caladoc and Petit Verdot) of grapevine, the quality of extracted DNA by the NucleoSpin method was higher than the modified Doyle and Doyle method. According to the results, the average value of

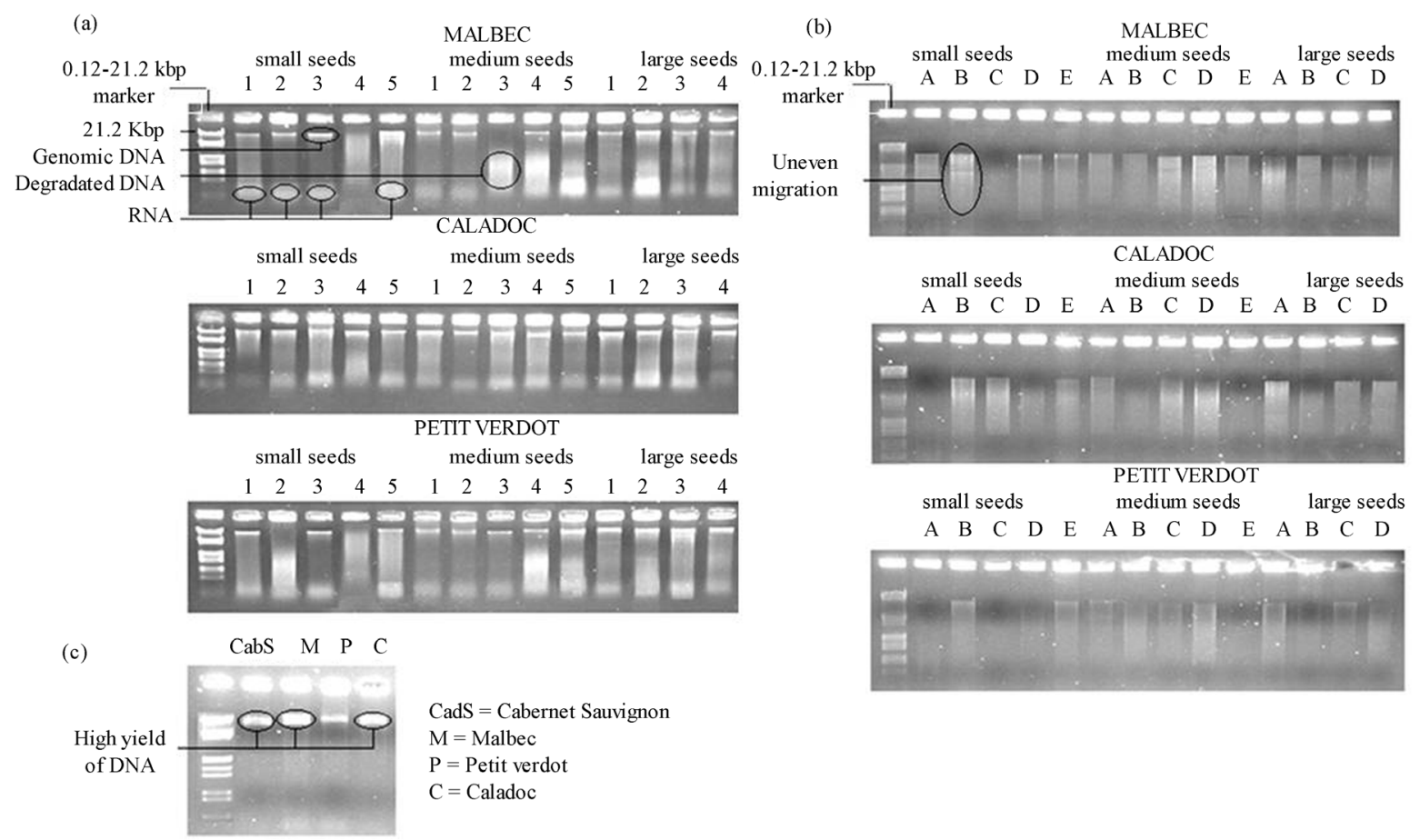

Figure 1. Ethidium bromide stained $0.6 \%$ agarose gel electrophoresis of DNA from seeds of three varieties of Vitis vinifera L. (Malbec, Petit Verdot and Caladoc). (a) extracted with the NucleoSpin method; (b) extracted with the modified Doyle and Doyle method; (c) stem DNA for reference material and positive control.

Table 1. Quality and quantity of DNA obtained from each extraction method.

\begin{tabular}{cccccccc}
\hline \multirow{2}{*}{ Variety } & $\begin{array}{c}\text { Seed weight } \\
\text { class }\end{array}$ & \multicolumn{3}{c}{ NucleoSpin Plant II method } & \multicolumn{3}{c}{ Modified Doyle \& Doyle method } \\
\cline { 3 - 8 } & $\begin{array}{c}\text { Seed weight } \\
(\mathrm{mg})\end{array}$ & $\begin{array}{c}\text { DNA quality } \\
260 / 280 \text { ratio }\end{array}$ & $\begin{array}{c}\text { DNA yield } \\
\left(\mathrm{ng} \cdot \mathrm{mg}^{-1}\right)\end{array}$ & $\begin{array}{c}\text { Seed weight } \\
(\mathrm{mg})\end{array}$ & $\begin{array}{c}\text { DNA quality } \\
260 / 280 \text { ratio }\end{array}$ & $\begin{array}{c}\text { DNA yield } \\
\left(\mathrm{ng} \cdot \mathrm{mg}^{-1}\right)\end{array}$ \\
\hline \multirow{3}{*}{ Malbec } & Small & $23.8 \pm 0.7$ & $1.9 \pm 0.1$ & $30.4 \pm 09.3$ & $22.6 \pm 1.3$ & $1.0 \pm 0.3$ & $232 \pm 242$ \\
& Medium & $27.4 \pm 0.8$ & $1.8 \pm 0.2$ & $28.1 \pm 09.3$ & $28.2 \pm 1.9$ & $0.9 \pm 0.1$ & $363 \pm 179$ \\
& Large & $32.3 \pm 1.4$ & $1.8 \pm 0.1$ & $24.8 \pm 05.2$ & $31.8 \pm 1.9$ & $0.9 \pm 0.1$ & $519 \pm 391$ \\
& Small & $23.3 \pm 1.1$ & $1.7 \pm 0.3$ & $38.2 \pm 03.8$ & $22.1 \pm 1.1$ & $0.9 \pm 0.1$ & $221 \pm 117$ \\
\multirow{3}{*}{ Caladoc } & Medium & $26.2 \pm 1.0$ & $1.8 \pm 0.1$ & $38.4 \pm 11.5$ & $25.5 \pm 0.3$ & $0.8 \pm 0.1$ & $602 \pm 114$ \\
& Large & $30.8 \pm 0.9$ & $1.8 \pm 0.1$ & $35.1 \pm 06.9$ & $30.6 \pm 0.4$ & $0.9 \pm 0.1$ & $694 \pm 090$ \\
& Small & $22.8 \pm 1.0$ & $1.9 \pm 0.3$ & $26.2 \pm 11.7$ & $23.2 \pm 1.3$ & $0.9 \pm 0.1$ & $478 \pm 295$ \\
& Medium & $27.3 \pm 1.6$ & $1.8 \pm 0.1$ & $24.8 \pm 01.1$ & $27.4 \pm 1.3$ & $0.9 \pm 0.1$ & $576 \pm 267$ \\
& Large & $32.4 \pm 1.8$ & $1.8 \pm 0.1$ & $28.8 \pm 07.9$ & $31.2 \pm 0.6$ & $0.9 \pm 0.1$ & $699 \pm 274$ \\
\hline
\end{tabular}


260/280 nm absorption ratio of the seed classes were ranged from 1.65 (small seeds of Caladoc) to 1.87 (small seeds of Petit Verdot and Malbec) and from 0.82 (medium seeds of Caladoc) to 1.03 (small seeds of Malbec) in the NucleoSpin kit method and modified Doyle and Doylemethod respectively. But considering all varieties, these values for the NucleoSpin method and the modified Doyle and Doyle method were 1.8 and 0.9 , respectively.

Using 20 - $35 \mathrm{mg}$ of single seed in this study, we obtained the most and the lowest DNA extraction values from NucleoSpin method, being $1082 \mathrm{ng}\left(14.4 \mathrm{ng} \cdot \mu \mathrm{L}^{-1}\right)$ from large seeds of Caladoc and $590 \mathrm{ng}\left(7.9 \mathrm{ng} \cdot \mu \mathrm{L}^{-1}\right)$ from small seeds of Petit Verdot, respectively. The average yield of extracted DNA in this protocol ranged from $24.8 \pm 5.2 \mathrm{ng} \cdot \mathrm{mg}^{-1}$ to $38.4 \pm 11.5 \mathrm{ng} \cdot \mathrm{mg}^{-1}$ corresponding to large seeds of Malbec and medium seeds of Caladoc, respectively. For each grapevine variety, Malbec, Caladoc and Petit Verdot, the mean average yield value was $28 \pm 8 \mathrm{ng} \cdot \mathrm{mg}^{-1}, 37 \pm 8 \mathrm{ng} \cdot \mathrm{mg}^{-1}$ and $27 \pm 8 \mathrm{ng} \cdot \mathrm{mg}^{-1}$, respectively. The mean value from Caladoc with this protocol was comparatively is higher than the other two varieties. NucleoSpin protocol can be used with samples up to $20 \mathrm{mg}$ of dry weight giving a typical yield of DNA between $1-30 \mu \mathrm{g}$ with an elution volume of $100 \mu \mathrm{L}$. In this study the resulted DNA yield was between $0.6 \mu$ g per 22.8 mg dry weight (small seed of Petit Verdot) and $1.1 \mu$ g per $30.8 \mathrm{mg}$, d.w. (large seed Caladoc).

The modified Doyle and Doyle method of extraction gave maximum DNA yield (Table 1). These values range between $221 \pm 117 \mathrm{ng} \cdot \mathrm{mg}^{-1}$ (small seeds of Caladoc) and $699 \pm 273.7 \mathrm{ng} \cdot \mathrm{mg}^{-1}$ (large seeds of Petit Verdot). However, it was heavily contaminated with polysaccharides and polyphenols as indicated by the A260/280 ratios $(<1.8)$. The suspensions of DNA samples were very viscous and light brown in colour. Upon electrophoresis on a $0.6 \%$ agarose gel, the DNA extracted by this method showed uneven migration, producing thick fire-like trailing smears with traces of contaminants (Figure 1(b)). Therefore this protocol was not efficient in getting rid of the polysaccharides and phenolic compounds. Isolation of DNA from seed tissues of Vitis vinifera is difficult due to high levels of polysaccharide and polyphenol contents. Similar results were found by Do and Adams [27] and Collins and Symons [28] from leaf tissues of Vitis vinifera.

\subsection{Estimating of Agarose Gel Electrophoresis}

The quality and quantity of DNA extracted from the NucleoSpin method and the modified Doyle and Doylemethod is shown in Figure 1. In the present study, among the two protocols examined, the NucleoSpin method proved efficacious compared to the modified Doyle and Doyle procedures. Upon electrophoresis on $0.6 \%$ agarose gel, thick, sharper and distinct bands were obtained (Figure 1(a)). The absence of smears indicates a high quality in the nucleic acids extracted from NucleoSpin indicating that only this method consistently yielded DNA suitable for PCR amplifications.

\subsection{Comparisons of Extracted DNA Quantities from NucleoSpin Method}

The NucleoSpin method resulting data from spectrophotometer were compared with a student t-test. In this study we compared extracted DNA concentration between seed classes of each variety and between varieties of each seed class. The comparison of extracted DNA quantities between the seed classes of each variety were shown in Table 2. According to the results of the comparison between seed classes of each variety, the significantly differences between small and large seeds as well as medium and large seeds of Petit Verdot grapevine were detected. The other varieties such as Malbec and Caladoc grapevine seed classes did not show significant differences between the seed classes. Table 3 shows the comparison of the extracted DNA quantities between the varieties of each seed class. When the varieties of each seed class were compared, significant differences between small and medium seed of Caladoc and Petit Verdot grapevine varieties as well as large seed of the Malbec and Caladoc grapevine varieties were shown.

\section{Conclusion}

In conclusion, the quality of DNA obtained with the NucleoSpin Plant II method was much better than the modified Doyle and Doyle even with the smallest seed having a weight of $20 \mathrm{mg}$. The modified Doyle and Doyle method was not suitable for DNA extraction from a single seed of grapevine as well as these kind of studies. In NucleoSpin method, the volume of elution buffer used in the elution steps was the most important parameter to obtain maximum amount of DNA concentration from a single seed. In the first elution step we used the same volume $(50 \mu \mathrm{L})$ of elution buffer according to the manufacturer specification, but in the second elution step, we 
Table 2. Comparison of extracted DNA quantities between seed classes of each variety.

\begin{tabular}{|c|c|c|c|c|c|c|}
\hline \multirow{2}{*}{ Variety } & \multirow{2}{*}{ Seed class } & \multicolumn{2}{|c|}{ DNA concentration $(\mathrm{ng} / \mu \mathrm{L})$} & \multicolumn{3}{|c|}{ Mean comparison between seed classes } \\
\hline & & Mean & SD & S vs $M$ & S vs $L$ & $M$ vs $L$ \\
\hline \multirow{3}{*}{ Malbec } & Small & 9.64 & 2.57 & \multirow{3}{*}{$p=0.789$} & \multirow{3}{*}{$p=0.546$} & \multirow{3}{*}{$\mathrm{p}=0.788$} \\
\hline & Medium & 10.18 & 2.93 & & & \\
\hline & Large & 10.68 & 2.07 & & & \\
\hline \multirow{3}{*}{ Caladoc } & Small & 11.82 & 0.78 & \multirow{3}{*}{$p=0.402$} & \multirow{3}{*}{$\mathrm{p}=0.082$} & \multirow{3}{*}{$\mathrm{p}=0.628$} \\
\hline & Medium & 13.36 & 3.40 & & & \\
\hline & Large & 14.42 & 2.49 & & & \\
\hline \multirow{3}{*}{ Petit Verdot } & Small & 7.86 & 2.85 & \multirow{3}{*}{$\mathrm{p}=0.447$} & \multirow{3}{*}{$\mathrm{p}=0.046^{*}$} & \multirow{3}{*}{$\mathrm{p}=0.033^{*}$} \\
\hline & Medium & 9.02 & 0.54 & & & \\
\hline & Large & 12.34 & 2.53 & & & \\
\hline
\end{tabular}

Values are means of 5 replicates \pm S.D.; ${ }^{*}$ significant at $\mathrm{p}=0.05$; S (small); M (medium); L (large).

Table 3. Comparison of extracted DNA quantities between varieties of each seed class.

\begin{tabular}{|c|c|c|c|c|c|c|}
\hline \multirow{2}{*}{ Seed class } & \multirow{2}{*}{ Variety } & \multicolumn{2}{|c|}{ DNA concentration $(\mathrm{ng} / \mu \mathrm{L})$} & \multicolumn{3}{|c|}{ Mean comparison between varieties } \\
\hline & & Mean & SD & M vs C & $\mathrm{M}$ vs $\mathrm{P}$ & C vs $P$ \\
\hline \multirow{3}{*}{ Small } & Malbec & 9.64 & 2.57 & \multirow{3}{*}{$p=0.143$} & \multirow{3}{*}{$\mathrm{p}=0.381$} & \multirow{3}{*}{$\mathrm{p}=0.028^{\prime}$} \\
\hline & Caladoc & 11.82 & 0.78 & & & \\
\hline & Petit Verdot & 7.86 & 2.85 & & & \\
\hline \multirow{3}{*}{ Medium } & Malbec & 10.18 & 2.93 & \multirow{3}{*}{$\mathrm{p}=0.194$} & \multirow{3}{*}{$\mathrm{p}=0.459$} & \multirow{3}{*}{$\mathrm{p}=0.036^{*}$} \\
\hline & Caladoc & 13.36 & 3.40 & & & \\
\hline & Petit Verdot & 9.02 & 0.54 & & & \\
\hline \multirow{3}{*}{ Large } & Malbec & 10.68 & 2.07 & \multirow{3}{*}{$\mathrm{p}=0.050^{*}$} & \multirow{3}{*}{$\mathrm{p}=0.339$} & \multirow{3}{*}{$\mathrm{p}=0.275$} \\
\hline & Caladoc & 14.42 & 2.49 & & & \\
\hline & Petit Verdot & 12.34 & 2.53 & & & \\
\hline
\end{tabular}

Values are means of 5 replicates \pm S.D.; ${ }^{*}$ significant at p = 0.05; M (Malbec); C (Caladoc); P (Petit Verdot).

used $25 \mu \mathrm{L}$ of elution buffer which helps to got maximum yield of DNA. The NucleoSpin method used in this study consistently yielded DNA suitable for PCR amplification from grapevine seeds, regardless of cultivars or seed size and thus suitable for further genetic studies.

\section{Acknowledgments}

This work has been supported by an Erasmus mundus MAHEVA scholarship between the Université Montpellier 2 (France) and the University of Colombo (Sri Lanka) and by the DAAM project 2012 AGEC 00053 from Generalitat de Catalunya. We would like to acknowledge Dr. Santiago Minguez head of the Institut Catala de la Vinya i el Vi (INCAVI), Spain to provide us his invaluable support to success this research.

\section{References}

[1] Arumuganathan, K. and Earle, E.D. (1991) Nuclear DNA Content of Some Important Plant Species. Plant Molecular Biology Reporter, 9, 208-218. http://dx.doi.org/10.1007/BF02672069

[2] Kikkert, J.R., Striem, M.J., Vidal, J.R., Wallace, P.G., Barnard, J. and Reisch, B.I. (2005) Long-Term Study of Somatic 
Embryogenesis from Anthers and Ovaries of 12 Grapevine (Vitis sp.) Genotypes. In Vitro Cellular \& Developmental Biology-Plant, 41, 232-239. http://dx.doi.org/10.1079/IVP2004609

[3] Akkurt, M., Welter, L., Maul, E., Topfer, L. and Zyprian, E. (2007) Development of SCAR Markers Linked to Powdery Mildew (Uncinulanecator) Resistance in Grapevine (Vitis vinifera L. and Vitis sp.). Molecular Breeding, 19, 103111. http://dx.doi.org/10.1007/s11032-006-9047-9

[4] Troggio, M., et al. (2007) A Dense Single-Nucleotide Polymorphism-Based Genetic Linkage Map of Grapevine (Vitis vinifera L.) Anchoring Pinot Noir Bacterial Artificial Chromosome Contigs. Genetics, 176, 2637-2650. http://dx.doi.org/10.1534/genetics.106.067462

[5] Wang, Q., Li, P., Hanania, U., Sahar, N., Mawassi, M., Gafny, R., Sela, I., Tanne, E. and Perl, A. (2005) Improvement of Agrobacterium-Mediated Transformation Efficiency and Transgenic Plant Regeneration of Vitis vinifera L. by Optimizing Selection Regimes and Utilizing Cryopreserved Cell Suspensions. Plant Science, 168, 565-571. http://dx.doi.org/10.1016/j.plantsci.2004.09.033

[6] Adam-Blondon, A.F., Roux, C., Claux, D., Butterlin, G., Merdinoglu, D. and This, P. (2004) Mapping 245 SSR Markers on the Vitis vinifera Genome: A Tool for Grape Genetics. Theoretical and Applied Genetics, 109, 1017-1027. http://dx.doi.org/10.1007/s00122-004-1704-y

[7] DiGaspero, G., Cipriani, G., Adam-Blondon, A.F. and Testolin, R. (2007) Linkage Maps of Grapevine Displaying the Chromosomal Locations of 420 Microsatellite Markers and 82 Markers for R-Gene Candidates. Theoretical and Applied Genetics, 114, 1249-1263. http://dx.doi.org/10.1007/s00122-007-0516-2

[8] Lodhi, M.A., Ye, G.N., Weeden, N.F. and Reisch, B.I. (1994) A Simple and Efficient Method for DNA Extraction from Grapevine Cultivars and Vitis Species. Plant Molecular Biology Reporter, 12, 6-13. http://dx.doi.org/10.1007/BF02668658

[9] Hanania, U., Velcheva, M., Sahar, N. and Perl, A. (2004) An Improved Method for Isolating High-Quality DNA from Vitis vinifera Nuclei. Plant Molecular Biology Reporter, 22, 173-177. http://dx.doi.org/10.1007/BF02772724

[10] Boso, S., Alonso-Villaverde, V., Martinez, M.C. and Kassemeyer, H.H. (2012) Quantification of Stilbenes in Vitis Genotypes with Different Levels of Resistance to Plasmopara viticola Infection. American Journal of Enology and Viticulture, 63, 419-423. http://dx.doi.org/10.5344/ajev.2012.11127

[11] Iandolino, A.B., Goes DaSilva, F., Lim, H., Cho, H., Williams, L.E. and Cook, D.R. (2004) High-Quality RNA, cDNA, and Derived EST Libraries from Grapevine (Vitis vinifera L.). Plant Molecular Biology Reporter, 22, 269-278. http://dx.doi.org/10.1007/BF02773137

[12] Murray, M.G. and Thompson, W.F. (1980) Rapid Isolation of High Molecular Weight Plant DNA. Nucleic Acids Research, 8, 4321-4325. http://dx.doi.org/10.1093/nar/8.19.4321

[13] Katterman, F.R.H. and Shattuck, V.L. (1983) An Effective Method of DNA Isolation from the Mature Leaves of Gossypium Species that Contain Large Amounts of Phenolic Terpenoids and Tannins. Preparative Biochemistry, 13, 347359. http://dx.doi.org/10.1080/00327488308068177

[14] Loomis, W.D. (1974) Overcoming Problems of Phenolic and Quinines in the Isolation of Plant Enzymes and Organelles. Methods in Enzymology, 31, 528-544. http://dx.doi.org/10.1016/0076-6879(74)31057-9

[15] Porebski, S., Bailey, L.G. and Baum, B.R. (1997) Modification of a CTAB DNA Extraction Protocol for Plants Containing High Polysaccharide and Polyphenol Components. Plant Molecular Biology Reporter, 15, 8-15. http://dx.doi.org/10.1007/BF02772108

[16] Fang, G., Hammer, S. and Grumet, R. (1992) A Quick and Inexpensive Method for Removing Polysaccharides from Plant Genomic DNA. BioTechniques, 13, 52-54.

[17] Aljanabi, S.M., Forget, L. and Dookun, A. (1999) An Improved and Rapid Protocol for the Isolation of Polysaccharide and Polyphenol Free Sugarcane DNA. Plant Molecular Biology Reporter, 17, 281.

http://dx.doi.org/10.1023/A:1007692929505

[18] Akkurt, M. (2012) Comparison between Modified DNA Extraction Protocols and Commercial Isolation Kits in Grapevine (Vitis vinifera L.). Genetics and Molecular Research, 11, 2342-2351. http://dx.doi.org/10.4238/2012.August.13.8

[19] Lemke, L., Rex, M., Zyprian, E. and Töpfer, R. (2011) A Simple, Inexpensive and Environmentally Friendly Method for High Throughput DNA Extraction from Grapevine (Vitis spp.). Vitis, 50, 7-10.

[20] Marsal, G., Baiges, I., Canals, F., Zamora, J.M. and Fort, F. (2011) A Fast, Efficient Method for Extracting DNA from Leaves, Stems, and Seeds of Vitis vinifera L. American Journal of Enology and Viticulture, 62, 376-381. http://dx.doi.org/10.5344/ajev.2011.10082

[21] Manen, J.F., Bouby, L., Dalnoki, O., Marinval, P., Turgay, M. and Schlumbaum, A. (2003) Microsatellites from Archaeological Vitis vinifera Seeds Allow a Tentative Assignment of the Geographical Origin of Ancient Cultivars. Journal of Archaeological Science, 30, 721-729. http://dx.doi.org/10.1016/S0305-4403(02)00244-3 
[22] Steenkamp, J., Wiid, I., Lourens, A. and Van Helden, P. (1994) Improved Method for DNA Extraction from Vitis vinifera. American Journal of Enology and Viticulture, 45, 102-106.

[23] Sambrook, J., Fritsch, E.F. and Maniatis, T.A. (1989) Molecular Cloning: A Laboratory Manual. 2nd Edition, Cold Spring Harbor Laboratory Press, New York, 397.

[24] Pandey, R., Adams, R.P. and Flournoy, L.E. (1996) Inhibition of Random Amplified Polymorphic DNAs (RAPDs) by Plant Polysaccharides. Plant Molecular Biology Reporter, 14, 17-22. http://dx.doi.org/10.1007/BF02671898

[25] Khanuja, S.P.S., Shasany, A.K., Darokar, M.P. and Kumar, S. (1999) Rapid Isolation of DNA from Dry and Fresh Samples of Plants Producing Large Amounts of Secondary Metabolites and Essential Oils. Plant Molecular Biology Reporter, 17, 74. http://dx.doi.org/10.1023/A:1007528101452

[26] Li, J.T., Yang, J., Chen, D.C., Zhang, X.L. and Tang, Z.S. (2007) An Optimized Mini-Preparation Method to Obtain High-Quality Genomic DNA from Mature Leaves of Sunflower. Genetics and Molecular Research, 6, 1064-1071.

[27] Do, N. and Adams, R.P. (1991) A Simple Technique of Removing Plant Polysaccharides Contaminants form DNA. BioTechniques, 10, 162, 164, 168.

[28] Collins, G.G. and Symons, R.H. (1992) Extraction of Nuclear DNA from Grape Vine Leaves by a Modified Procedure. Plant Molecular Biology Reporter, 10, 233-235. http://dx.doi.org/10.1007/BF02668355 
Scientific Research Publishing (SCIRP) is one of the largest Open Access journal publishers. It is currently publishing more than 200 open access, online, peer-reviewed journals covering a wide range of academic disciplines. SCIRP serves the worldwide academic communities and contributes to the progress and application of science with its publication.

Other selected journals from SCIRP are listed as below. Submit your manuscript to us via either submit@scirp.org or Online Submission Portal.
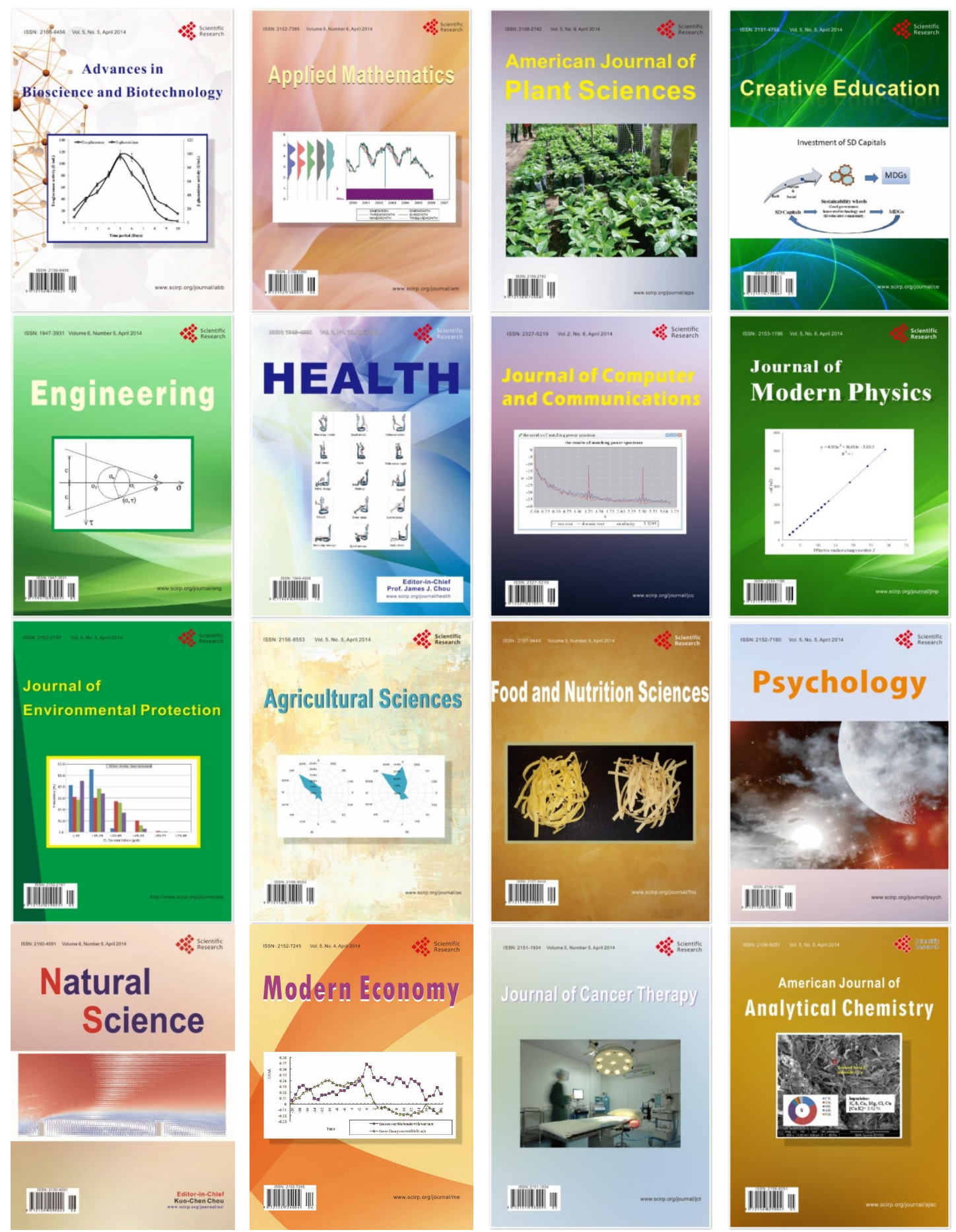